\title{
DIFFERENCES IN THE RURAL STRUCTURE OF SLOVAKIA IN THE CONTEXT OF SOCIO-SPATIAL POLARISATION
}

\author{
Lucia MáliKovÁ, Michal KlobuČNíK \\ Department of Human Geography and Demography, Faculty of Natural Sciences, Comenius University in \\ Bratislava, Slovakia
}

Manuscript received: December 21, 2016

Revised version: April 10, 2017

\begin{abstract}
MÁliková L., KLOBUČNík M., 2017. Differences in the rural structure of Slovakia in the context of socio-spatial polarisation. Quaestiones Geographicae 36(2), Bogucki Wydawnictwo Naukowe, Poznań, pp. 125-140, 2 tables, 2 figs.

ABSTRACT: This study is devoted to socio-spatial polarisation with regard to the rural environment in Slovakia. In fact, ongoing polarisation processes do not take place only in the rural-urban continuum, but within every single category as well. This is evident especially in the rural environment, which has begun to change significantly in terms of its structure and to diversify to a greater extent. As a result, some parts of the countryside began to stagnate and decline gradually. These parts of the rural environment can thus be referred to as marginal, peripheral. With respect to the proclaimed diversity of the rural environment, this study focuses on selected rural structures, namely mountain areas, the borderland, and the area at the intersection of those two structures. Generally, these parts of the rural environment are often confronted with the phenomenon of marginality and peripherality, and because of the given local predisposition are even more vulnerable to its manifestations. Taking into account the dynamism and multidimensional character of this phenomenon, we can further assume that its manifestation changes in time and space. With the use of ANOVA, we examine a set of selected indicators of socio-spatial polarisation and verify whether and to what extent this dynamism depends on the character of diversified rural structures.
\end{abstract}

KEY WORDS: rural structures, marginality, peripherality, polarisation, mountain areas, borderland, ANOVA

Corresponding author: Lucia Máliková, Department of Human Geography and Demography, Faculty of Natural Sciences, Comenius University in Bratislava, Slovakia, Ilkovičova 6, Mlynská dolina, 842 15, Bratislava, Slovakia; e-mail: malikova@fns. uniba.sk

\section{Introduction}

"In the beginning there was a landscape. Smart, strict, self-contained. Landscape in itself and for itself. Then came the man."

Milan Rúfus (Klinda 2007: 3)

The relationship between man and landscape, and particularly the impact of society on the landscape, can be interpreted in two ways with respect to the above statement. On the one hand, a positive relationship is outlined when man or society enters this environment, changes and transforms it from an enclosed space to the space for the benefit of the whole society and the 
environment as such. In this case, the landscape or let's say the environment is in the spotlight. On the other hand, a negative undertone is also present here, when man or society with their own activity disrupt the historical harmony of the environment, and the environment itself is being sidelined, marginalised. Yet in these initial thoughts, a certain element of imbalance, inconsistency and even polarisation appears, which is increasingly manifested not only in the society - environment relationship, but within the environment itself and ultimately in society as well. Thus, the polarisation of society and especially the phenomenon of marginality and peripherality surely cannot be considered only as topics of today, and it appears in both, lay discourses as well as in the scientific community. On the contrary, with its development and under the impact of transformation and globalisation processes, this issue is becoming even more justified. It manifests itself most significantly in rural areas, not only in terms of spatiality, since they constitute a significant area ( $80 \%$ of the EU and $86 \%$ of the Slovak Republic is rural), but also due to a greater tendency of rural areas to fall behind in socio-economic growth and overall development of society. Moreover, rural-urban divisions have deepened, creating the image of the rural as an 'outsider' in society and rurality as synonymous with 'backwardness' (Máliková et al. 2016). Moreover, the vulnerability of the Slovak rural environment carries traces of the social and economic transformation which has influenced its spatial organisation, the position within the regional structure of the country, and even its marginalisation. Not that spatial polarisation and inequalities in society did not exist before 1989, but after the regime has changed, these issues have become more apparent and the social as well as academic demand for their solution even more vehement (Mikuš et al. 2016). In this context, an interesting view is presented by Falt'an et al. (1995), emphasising that marginality cannot be understood simply as a status quo, or a phenomenon that appeared after 1989, but as a process (marginalisation) formed by socio-economic changes and the historical development of society over time, influencing the precarious situation of a certain region either positively (reducing marginality) or negatively (increasing marginality). However, with this in mind, it is necessary to realise that even rural space is highly heterogeneous, which is why socio-spatial polarisation can be manifested differently here, or ultimately even not at all. All these considerations bring us to the complex issue presented in this study through the lens of theoretical, methodological and empirical findings.

In the theoretical background, the conceptualisation of socio-spatial polarisation in the context of rural areas, its development and specific position within the settlement structure in Slovakia is emphasised. We build on concepts relevant in terms of the changing character of rurality and the position of this space in the system of regional structuring, such as the concepts of locality and rural restructuring. Special attention is paid to areas that are most likely to fall behind in terms of socio-spatial polarisation. Those are generally mountain areas and borderland zones, mainly because of their physical-geographic predisposition which corresponds to the traditional perception of polarisation in terms of the core-periphery model (Leimgruber 1994, 2004; Schmidt 1998), and the extended concept of core-periphery-marginality (Andreoli 1994).

In terms of methodological and empirical aspects, we analyse quite an extensive set of statistical data in a longer-term perspective with the use of ANOVA (analysis of variance) and other partial methodological approaches, and try to point out the position of diversified ruralities within the regional structure of Slovakia in the context of their socio-spatial polarisation. The key hypothesis in this study is that marginality and peripherality (socio-spatial polarisation) is expressed differently in specific types of rural structures and that its manifestation changes over time. Further discussion on the verification or rejection of this hypothesis is presented in the final part of the study.

\section{Key theoretical concepts}

Rural areas represent nowadays quite a diversified space, which differs in its nature, appearance or even functionality from one place to another as a result of long-term historical development as well as the current development of society. The concept of rurality keeps changing while resisting the traditional interpretation of 
rurality as a geographically limited place to its understanding through a set of cultural and social constructs which create rural space (Gregory et al. 2009). Thus, a comprehensive understanding of rurality in its complexity needs to be approached through the lens of different concepts in which rural space and its perception is being shaped in its current form. Moreover, the socio-spatial polarisation of society has to be taken into account, since, along with changes in the conceptual framework of rurality, the phenomenon of marginality and peripherality (in other words polarisation) and its manifestation across rural space keeps changing as well. Therefore, in the following section our attention is devoted to some rural concepts (namely those of locality and rural restructuring) discussed in a wide range of studies reflecting this topic in academic research.

\section{Locality}

The concept of locality represents a transition in the research on rural areas and in approaches to the delimitation of rurality. Halfacree (1993, 2006) considers locality to be one of the possible approaches to the definition of rurality in terms of specific and significant types of locality. Generally, this approach has found application especially in British rural geography, where it still prevails (Woods 2009). An essential conceptual framework concerns critical radicalism later complemented by post-structuralist approaches. The traditional urban-rural dichotomy is neglected in favour of an effort to define rural space per se, not only in relation to urban space (Novotný et al. 2015). It follows from the perception of rurality as a space highly complicated and socially diversified for its actors and their ability to self-express local structures and causal relationships within them (Murdoch, Marsden 1994). Perhaps we can talk about an endeavour to redefine and reconquer rural areas as such (Marek 2004).

This diversity in the interpretation of rurality is connected to a certain extent with the above-mentioned fact that rural space has become even more socially diversified and complex, and impossible to be universally defined. On the contrary, as pointed out by Hruška (2014), rural research requires narrowing down the research focus, conducting research at a lower hierarchical level, locality formed not only as a product of broader causal relationships at the global or national level, but above all by the very action of local structures and their relationships. However, the locality concept also meets criticism, since it presupposes the existence of specific social, economic and political processes and links typical of rural space. This basic assumption, however, was quickly refuted, since there are no such processes that would be specific only to the rural or urban environment, but various social, economic and political processes operate in these environments rather differently (Novotný et al. 2015). Similarly, Giddens (1984), Halfacree (1993), Hoggart (1990) and Cloke (2006) draw attention to the ambiguity in determining what categorises a certain locality as rural, while it is only this determination that represents a key element in order to recognise rural localities as an individual research category. In this context Hoggart (1990) adds that intra-rural differences may be huge while similarities between the rural and the urban may be negligible. Appadurai (1997) even argues that an ideal approach to determine locality as a real social construct does not exist. Moreover, terms such as space, place, locality have their strengths and weaknesses. Despite the criticism mentioned above and the fact that rural areas as specific units for reseach in politico-economic approaches de facto do not exist, locality remains an undoubtedly significant category (Hruška 2014).

\section{Rural restructuring}

Under the influence of the global transformation of society, rural areas have begun to change significantly in terms of their social structure, diversification of economic activities, or even the visual appearance of traditional rurality. These changes are not simple at all, on the contrary, it is a set of substantial, continuous and relatively rapid ongoing changes influenced by the changing trends in evolving society reflecting technological progress and the impact of globalisation. Their relevance was even more emphasised by the statement that "at the dawn of a new millennium Europe's rural areas are confronted with the task of re-inventing themselves" (Labrianidis 2004: 1). Common features of these changes occurring in the current rural environment are primarily their pace, endurance and interconnectedness (Woods 2005). The concept related to 
the rural change, as suggested by Ilbery (1998), follows from the assumption that these changes are of a multidimensional nature and therefore rural areas cannot be further seen as marginal space with respect to economic, social and political changes. Thus, the need for a new conceptual framework arises not only from the historical marginalisation of rural issues in social sciences, but especially from the importance and merits of those changes (Marsden et al. 1993).

The complex notion of those changes taking place in rural areas, forming and amending the character of the rural landscape in both, inner relations as well as the outer appearance, is usually referred to as rural restructuring (Marsden et al. 1990; Marsden et al. 1993; Ilbery 1998; Woods 2005; Creamer et al. 2009; Halseth et al. 2010; Meredith 2010; Winchell et al. 2010). It relates not only to the changed meaning and interpretation of the term 'rural', but also to changes in agriculture and the rural economy transforming the social and demographic structure of rural areas, and to environmental changes as well. Hoggart and Paniagua (2001a) add that this concept also includes the impact of current factors contributing to a permanent transformation of rural areas. In this context, Woods (2005) points out that within the ongoing transformation and rural restructuring, the focus shifts from emphasising the space as such to rather specific places. This reaffirms the great diversity and heterogeneity of rural areas (Woods 2010). Different forms of rural restructuring are presented in the study by McDonagh et al. (2015), where these authors emphasise the diverse dynamism of restructuring processes in the context of globalisation and socalled 'uneven geography' of the globally transformed rural space.

Regardless of how we look at the changing nature of rurality, when applying the concept of rural restructuring it is necessary to consider its confrontation with the local conditions and processes that have shaped and remodeled a specific rural area. Neither can we identify only one rural space in its diversity (Cloke, Milbourne 1992; Murdoch, Pratt 1993), and the concept of rural restructuring cannot be considered without the specific determinants of a certain geographical area which are subject to various forms and degrees of change (Murdoch, Marsden 1994; Goodwin, Cloke, Milbourne 1995; Ilbery 1998; Marsden
1998), or even directly equated with all changes taking place in rural areas (Hoggart, Paniagua 2001b; Meredith 2010). The transformation of the rural environment and rural restructuring can be applied fairly well especially in post-socialist countries, including Slovakia, where the formation of this space was influenced by a comprehensive transformation of society. An analysis of rural areas in this context is provided by Gajdoš (2000), Zubriczký (2000), Buchta (2003), Ira (2003), Danglová (2006), Gajdoš and Pašiak (2008), Danglová (2005), or Fáziková (2006).

With respect to rural restructuring, many authors consistently add that these changes transform rural areas not only in a positive sense, but due to a wide range of social, economic and political factors they might lead to uneven development and increase differences in their internal structure, a sign which can be considered a characteristic feature of transforming rurality (Ilbery 1998; Marsden 1998; Gajdoš, Pašiak 2008). Tykkyläinen (1998) emphasises that marginalisation can be regarded as a consequence of many factors related to the process of rural restructuring. Accompanying signs of the changing face of the rural environment are therefore also specific issues that arise in a certain area and augur its gradual deprivation and decline (Novotná 2011). The main problem concerns the fact that since rural areas are increasingly heterogeneous, the challenges affecting them are diversified as well. However, in a wider time-space context it can be argued that even in today's modern society new problems appear, for instance in terms of the quality of life or local identity and the renewal of traditional values (Kubeš 2000; Danglová 2006; Binek et al. 2010, 2011; Novotná 2011), some of them carrying a historical influence, such as unemployment, infrastructure or population ageing, identified by Pacione (1984) already in the early 1980s.

With the changing approaches to rurality, the character of rural areas and their characteristic features change as well, while they become increasingly heterogeneous and diversified. As a result, many authors have adopted a way of defining 'rural' through a set of characteristic features and symbols typical of rural areas. The traditional view of rurality in terms of low population density, poor infrastructure, lower employment in the second and third sectors of 
the economy, or a significant share of agricultural land use and forestry can be found in Clout (1982), Pacione (1984) and Hoggart (1988). This perception corresponds more with the traditional view of rurality as backwardness, and of rural areas as areas lagging behind (Halseth et al. 2010; Novotná 2011; Woods 2011), while, as emphasised by McDonagh (2001), today's rural areas keep being reconfigured and redefined in the context of modernisation, market economy, increased mobility and spatial diversity. Given the heterogeneous nature of the current rural space, it is more than just desirable to adopt a holistic approach that allows us to look at this issue from a broader perspective, reflecting the environmental, economic and social dimensions of rural areas (Ferrao et al. 2003). Diversity which implies rural areas may ultimately be expressed by the statement that "there is not one [rural] but there are many" (Murdoch, Pratt 1993: 425).

\section{Interpretation of the rural structure with a focus on mountain areas and the borderland}

The recognition that rural areas as such represent not only a kind of territory on the basis of the population and population density, but they are rather a reflection of the specific patterns of economic behaviour as well as social and cultural life, encouraged the present authors to perceive them as a comprehensive rural system (Lier 1996; Spišiak 1998) or rural structures (Spišiak 2005; Spišiak et al. 2005). From this point of view, a rural system, or rural structures, are rural areas viewed through the lens of mutually interconnected relations. Such a system can be seen as a certain autonomous unit, an open system influenced by the outside world, or let's say exogenous inputs (for example the urban environment) apart from the internal relationships (Lier 1996). A rural system then represents the whole rural environment, a complex of multidimensional relations and linkages creating a highly diversified space. This diversity can be recognised not only in various interpretations and delimitations of rurality, in a wide spectrum of rural typologies, but above all in the application level, as highlighted by a number of authors. The importance of the application level of rural geography itself was already highlighted by Cloke (1980), who appealed to a need for appropriate theoretical and methodological approaches to the analysis of rural space allowing closer cooperation with the planning practice. Such research on rural areas reflected initially the need to respond to the rural crisis related to the model of society development (Shucksmith 1990; Cloke, Milbourne 1992), later enriched by the dimension of sustainability (Sasaki et al. 1996; Ira, Huba 1999; Spišiak 2003) and efforts to revitalise and develop the rural landscape (Chambers 1983; Moseley 2003; Binek et al. 2007; Binek, Svobodová 2009), or even an analysis of processes taking place in the rural environment (Zubriczký 2002; Woods 2005; Winchell et al. 2010).

As highlighted by the applicability of the research mentioned above with respect to the proclaimed diversity of the rural environment, it is important that rural research should take into account its specificity and uniqueness. In this case, the greatest emphasis is put on the most vulnerable areas more prone to becoming marginal and peripheral. Since there is no single universally valid rural typology at the local level in Slovakia, in the following analysis we reflect on two selected types of rural structure which seem to play a significant role in the context of the socio-spatial polarisation of rural areas (with a focus on the phenomenon of marginality and peripherality). We look closer at two specific rural structures: mountain areas and the borderland zone, plus one additional structure formed at the intersection of those two structures. Their greater vulnerability to marginality derives not only from their geographical characteristics (whether in a horizontal view - peripheral location along the border, or a vertical view - peripheral location in terms of altitude), but also from various historical and cultural aspects. Mountain areas represent an extreme case of agriculturally marginal areas, bearing also other features of marginality and peripherality (Schmidt 2007) which are often a basis for their further socio-economic marginalisation (Leimgruber 1994).

Although mountain areas are usually not of key relevance in rural development as such, in many countries they represent a significant share of the whole area (Jussila et al. 1998). In terms of the criteria of various institutions, approximately a half of Slovakia is covered by mountains. The 
classification of less-favoured areas (LFAs) according to the criteria of the Council of European Communities (1257/1999 Art. 16-21) seems to be the most appropriate in terms of research on polarisation, since mountain areas ${ }^{1}$ here are identified as disadvantaged, particularly in relation to agricultural production, since the adverse conditions such as high altitude, steep slopes, poor soil fertility together with specific local economic and social conditions make the cost per unit of production in farming higher than the average (Information service VUPOP). Thus, mountain areas represent an extreme case of agriculturally marginal areas where other kinds of marginality, e.g. social, may interfere (Hrabánková et al. 2009). Pelc (2011) stresses that especially at the local level the topography of mountain areas may often develop into deterioration of accessibility to such an extent that the depopulation process will be irreversible here. On the other hand, he points out to the importance of a successful adaptation of mountain areas to a general nationwide situation, which often goes beyond physical geographical disadvantage and ultimately may lead to their socio-economic development. In response to the various forms of disadvantage and marginalisation of mountain areas in the Slovak regional structure, several analyses have been undertaken, for example Spišiak et al. (2005), Bezák and Mitchley (2014) or Máliková (2014).

On the other hand, borderland is often linked with geometric marginality and peripherality implying the core-periphery model. However, a barrier effect of the borders and their impact on the status and functioning of the borderland has decreased under the influence of globalisation and integration processes, resulting in the opening of the borders and thriving cross-border cooperation, which is generally referred

In the LFA categorisation mountain areas are identified according to the following criteria (VUPOP):

- average altitude more than or equal to 700 metres above sea level,

- average altitude more than or equal to 600 metres above sea level and less than 700 metres above sea level,

- slope relief exceeds or is equal to $20 \%\left(11.18^{\circ}\right)$ on more than $1 / 2$ of the whole area,

- average altitude exceeds or is equal to 500 metres above sea level and less than 600 metres above sea level and with slope relief exceeding $15 \%\left(8.31^{\circ}\right)$ on more than $1 / 2$ of the whole area. to as a de-bordering process (Newman 2006; Nelles, Durand 2012). From the spatial point of view, these areas offer the possibility of mutual cross-border networking determined by the permeability of the border itself as well as by the spatial distribution, structure and accessibility of settlements on both sides of the border (Halás 2005). In accordance with Paasi's (2012) assumptions, the importance of the borderland becomes increasingly complex and its understanding requires thinking in a broader spatial context. The borderland comprises a significant share of rural areas, often described as periphery, but as pointed out by a number of academics, although the geographical location plays an increasingly important role, with the declining importance of the borders as a barrier and increasing cross-border linkages the perception of geometric aspects shifts the emphasis from distance to accessibility (Jeřábek et al. 2004; McDonagh 2002). Thus, in the borderland one can identify both, peripheries and centres (Anderson, O’Dowd 1999; O’Dowd 2001; Havlíček 2003).

Although the borderland and border relations are a common research topic in academic disciplines, their exact delimitation is ambiguous. Because of that, in this study we will build on the methodology used in Máliková et al. (2015), where the borderland was identified with the use of a simple zoning method, buffering, based on geometric aspects using a direct air distance from the border. This delimitation was based on geometric aspects using the administrative criterion as a zone of municipalities located along the borders. Application of a $20-\mathrm{km}$ distance and a centroid as the spatial operator seemed to be the most appropriate solution with respect to the number of municipalities and the spatial integrity of Slovakia.

Last but not least, in the literature there are quite a number of studies where the borderland or mountain areas are confronted with socio-spatial polarisation (McDonagh 2002; Havlíček 2003; Jeřábek et al. 2004; Halás 2005, 2008; Spišiak et al. 2005; Leimgruber et al.; Schmidt 2011; Máliková 2014). However, it is necessary to point out that in our approach we deal with these specific types of rural structures in terms of their greater predisposition and vulnerability to socio-spatial polarisation rather than considering them as explicitly marginal or peripheral areas. 


\section{Research design}

As stated in the previous section, we analyse selected rural structures in terms of socio-spatial polarisation, especially the phenomenon of marginality and peripherality. We focus on mountain areas, borderland zones and the area at their intersection, which represent approximately $2 / 3$ of Slovakia. As the main observation unit we chose the local level - municipalities. Although locally based studies are rather an exception in this kind of research and occur more or less occasionally (Spišiak 2000; Pileček 2005; Džupinová et al. 2008; Halás 2008), as pointed out by Leimgruber (2004), it is really the lowest hierarchical level which allows us to reveal specific aspects and a fair view of the phenomenon of marginality and peripherality across space, not to mention the heterogeneity of rural areas, where this is of vital importance. The selection of observation units, however, takes into account the size of the database as well as the specific time frame. In both cases, it is necessary to consider the representativeness of the data in terms of the analysed phenomenon as well as a sufficient period when the potential changes and trends can be observed. As pointed out by Michalek (2015), in the research on the socio-spatial polarisation and relevant changes in Slovak society, two consecutive time periods appear to be the most appropriate when qualitative and quantitative changes can be recognised in a very short time horizon. With respect to the dynamic historical and social development in Slovakia after 1989, for our analysis we chose a period of two decades recorded in the census data from 1991, 2001 and 2011. Census data, unlike other selective statistics, provide a relatively large dataset obtained by full investigation at the local level. Although Chajdiak (2015) notes that because of the population's mistrust as to the proclaimed anonymous character of a census, the latest censuses had a tendency to provide rather incomplete data, which may reduce their quality and credibility. On the other hand, census data can be considered universal in terms of their use in various fields of life (and research), and in particular as a basis for the construction of an image of Slovak society and its development over time (Juhaščíková et al. 2015).

And although the census data do not allow us to follow year-to-year fluctuations in individual indicators, they provide valuable information and the traceability of certain trends over time. The three selected census years - 1991, 2011 and 2011 - are especially relevant in terms

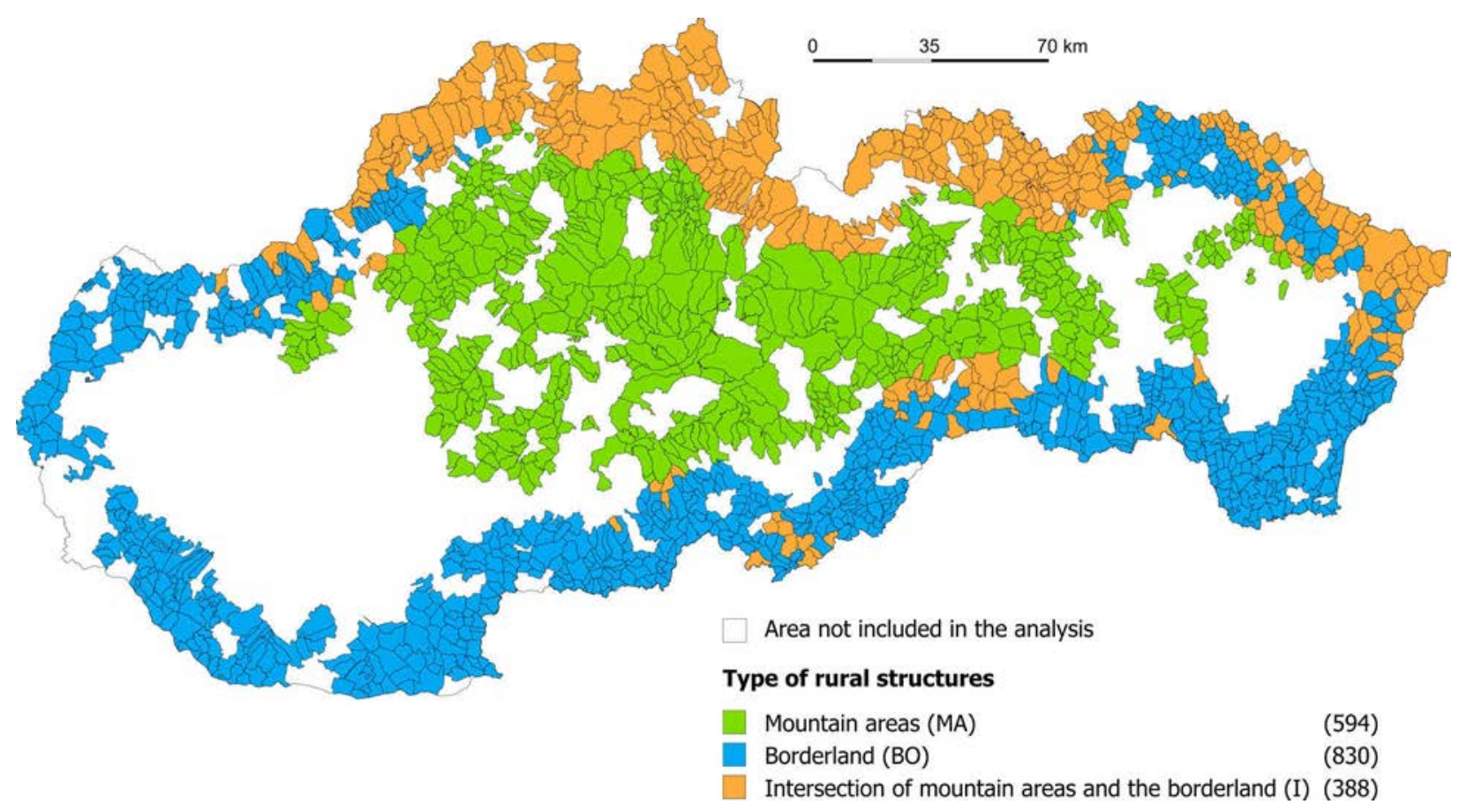

Fig. 1. Rural structures in Slovakia selected for the analysis. Source: authors' elaboration. 


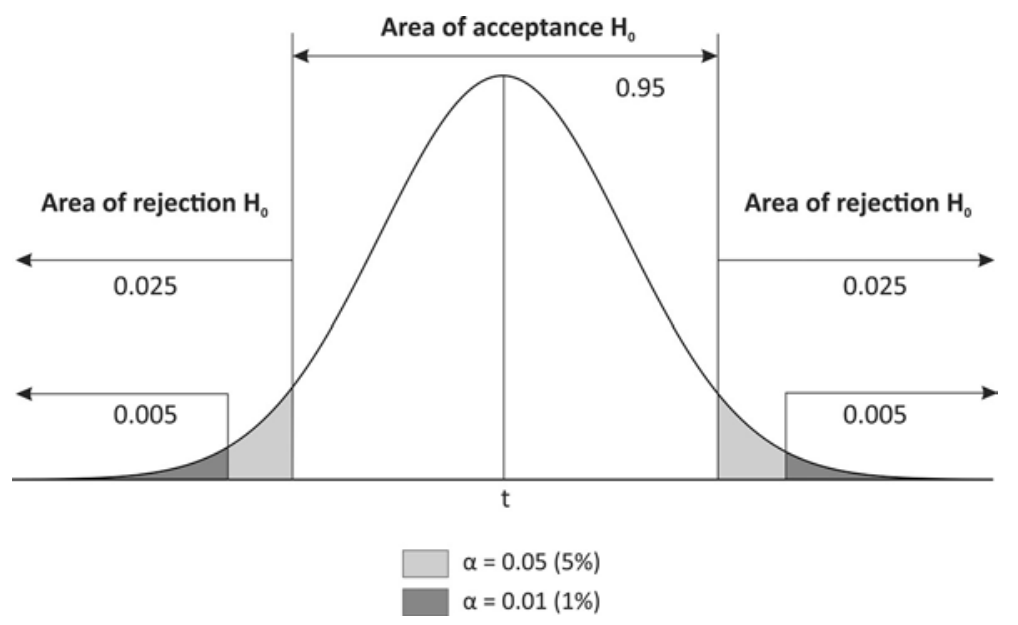

Fig. 2. Areas of the acceptance and rejection of a hypothesis in ANOVA. Source: authors' elaboration.

of monitoring the socio-spatial polarisation of society, mainly because of the important historical and political events that occurred in the inter-census period and are reflected in the census database. Following those assumptions and with respect to different administrative divisions of Slovakia in each period (related to the merging and splitting of municipalities), we came to the final set of 1,812 municipalities considered in our analysis (Fig. 1).

The academic discussion of methodological problems in evaluating socio-spatial polarisation refers to the fact that the use of a coherent set of indicators is relatively uncommon. Therefore, in the selection of relevant indicators of socio-spatial polarisation in the Slovak rural context we built our research on the existing research framework where indicators of an economic, social, geometric or infrastructural nature are the most commonly used, which corresponds with the main approaches to the study of marginality and peripherality developed by Leimgruber $(1994,2004)$, Sommers and Mehretu (1998), and Schmidt (1998). Moreover, the research on the polarisation of space encounters a particular problem of the lack of retrospective data as well as of the comparability of data, since the definition of a particular indicator, its character, and the size of the relevant data collection keep changing over time (Havliček et al. 2005). In this respect, Michálek (2015) adds that while selecting appropriate data, the emphasis should be on such attributes as clarity, compatibility, comparability, operability, and the informative value.
On the basis of the above criteria, we selected 14 indicators (see the following section for more details) and tested them for their mutual independence, which we confirmed by Pearson's correlation coefficient. The indicators were regarded as equally important because of the difficulty in assessing the importance of various aspects which may have different intensity and impact across the selected types of rural structures. Building on the heterogeneous nature of the rural environment, we assumed that the importance and influence of individual factors may vary both, with regard to the diversified territory as well as in relation to the analysed period. This assumption was tested using one-way ANOVA $^{2}$ followed by Tukey's HSD test, which enabled us to identify similarities and differences in the values of the selected indicators in the analysed types of rural structures. As stated by Markechová et al. (2011), ANOVA is one of the most widely used research methods in natural and social sciences. It is a statistical method developed to compare mean values of several basic datasets, while the value of quantitative variables may depend on one or more qualitative variables, so-called factors. We applied this method in order to determine the impact of different rural structures on the value of a particular indicator over the last two decades. The standard significance level was $\alpha=0.05$ (5\%) (Fig. 2).

2 More detailed information about ANOVA can be found in Heřmanová (1991), Chajdiak et al. (1997), Rogerson (2001), Miller and Haden (2006), and Markechová et al. (2011). 


\section{Role of space and place in the context of socio-spatial polarisation}

Time and space are two basic attributes that play a significant role in research on marginality and peripherality. As many experts have pointed out, this is a phenomenon of considerable dynamism, which makes it appropriate to consider it in terms of a "process" rather than a "status" (Falt'an et al. 1995). At the same time, we have to think of the multi-dimensional nature of this phenomenon, while its dynamism may be highly pronounced (especially in terms of economic factors) or less intensive (particularly in terms of more stable aspects related to location, population density and infrastructure). Similarly, this process can evolve either positively (mitigation of marginality) or in a negative direction (the deepening of marginality). Those considerations are proved by the organisation of Slovakia's regional structure, implying social changes from the global to the local level (Korec 2005). The absence, or rather neglect, of regional differences and inequalities, particularly before 1989, and their later rediscovery and acceptance caused an impression of sudden significant polarisation of the regional structure and the need to address socio-spatial polarisation and related issues, not only in terms of evident geographical differences from east to west or north to south, but especially in the more detailed view of urban-rural differences, and because of the heterogeneous character of rurality itself, even in the diversified rural structures as such. Finally, dynamism is therefore characteristic not only of marginality and peripherality and processes of socio-spatial polarisation, but also of rural areas, which appear to be relatively stable in terms of physical-geographical predispositions, but due to their specific position in the context of socio-economic status are subject of more or less equal dynamism.

Especially when considering the Slovak rural environment, which has changed significantly (and keeps changing constantly) mainly due to a far-reaching transformation, this dynamism is even more evident. Gajdoš and Pašiak (2008) evaluate those changes in rural areas as vast and multidimensional, producing both positive and negative effects, continuing to these days. They are mainly associated with economic and demographic changes as well as with the transforming sustainability of these areas, often reflected across the Slovak academia (Ira, Huba 1999; Podolák 1999; Buchta 2003).

With respect to the above, we submitted the selected types of rural structures to a deeper analysis in order to highlight the dynamic nature and the changing significance of each type of rural structure over time, particularly in terms of the 14 selected indicators implying the phenomenon of marginality and peripherality. We applied the ANOVA method to test the following working hypotheses:

- $\mathrm{H}_{0}$ - a specific type of rural structure has no statistically significant effect (at the 5\% significance level) on the values of the analysed indicators;

- $\mathrm{H}_{1}$ - a specific type of rural structure has a statistically significant effect (at the 5\% significance level) on the values of the analysed indicators.

The indicators were chosen deliberately so that we could refer to different dimensions of marginality and peripherality in terms of the most common approaches to the study of this problem (Leimgruber 1994, 2004; Sommers, Mehretu 1998; Schmidt 1998), although this set does not exhaustively cover all its aspects, which is beyond our ability with respect to data availability and the difficulty of their processing. The indicators are as follows: growth index (I1), population density (I2), net migration (I3), education (I4), economic dependence (I5), ageing (I6), unemployment rate (I7), ethnic diversity (I8), distance from a centre with min. 20,000 inhabitants (I9), share of indigenous inhabitants (I10), share of economically active people leaving for work (I11), progressivity of economic structure (I2), share of unoccupied dwellings (I13), and infrastructural facilities (I14).

In the three types of rural structures, all those indicators were significantly reflected, and as Table 1 shows, differences in their values changed both in time and space. Thus, in the analysed years 1991, 2001 and 2011 we can observe the changing importance of space (every specific type of rural structure) in all the analysed indicators. The continuous increase in significance (in terms of reducing the level of significance) was observed in the case of three social indicators (I1, I2, I4) and one infrastructural indicator (I14), with a statistically significant effect of space in 
Table 1. Results of ANOVA analysis.

\begin{tabular}{|c|c|c|c|}
\hline \multirow{2}{*}{ Indicator } & \multicolumn{3}{|c|}{ p-value } \\
\cline { 2 - 4 } & 1991 & 2001 & 2011 \\
\hline I1 & $\mathrm{n} / \mathrm{s}$ & $\mathrm{n} / \mathrm{s}$ & 0,001 \\
\hline $\mathrm{I} 2$ & $\mathrm{n} / \mathrm{s}$ & $\mathrm{n} / \mathrm{s}$ & 0,043 \\
\hline $\mathrm{I} 3$ & 0,002 & 0,001 & $\mathrm{n} / \mathrm{s}$ \\
\hline $\mathrm{I} 4$ & $6,42 \mathrm{E}-10$ & $1,57 \mathrm{E}-10$ & $1,99 \mathrm{E}-11$ \\
\hline $\mathrm{I} 5$ & $\mathrm{n} / \mathrm{s}$ & $3,22 \mathrm{E}-13$ & $1,62 \mathrm{E}-10$ \\
\hline $\mathrm{I} 6$ & $\mathrm{n} / \mathrm{s}$ & 0,005 & $\mathrm{n}, 000$ \\
\hline $\mathrm{I} 7$ & 0,001 & $2,30 \mathrm{E}-16$ & $\mathrm{n} / \mathrm{s}$ \\
\hline $\mathrm{I} 8$ & 0,015 & $\mathrm{n} / \mathrm{s}$ & $9,73 \mathrm{E}-24$ \\
\hline $\mathrm{I} 9$ & $2,23 \mathrm{E}-29$ & $1,10 \mathrm{E}-24$ & $\mathrm{n} / \mathrm{s}$ \\
\hline I10 & $4,44 \mathrm{E}-32$ & $1,79 \mathrm{E}-15$ & $1,24 \mathrm{E}-11$ \\
\hline I11 & $5,34 \mathrm{E}-19$ & $2,21 \mathrm{E}-10$ & $9,03 \mathrm{E}-8$ \\
\hline I12 & $6,52 \mathrm{E}-10$ & 0,001 & $1,38 \mathrm{E}-14$ \\
\hline I13 & $1,56 \mathrm{E}-9$ & $1,08 \mathrm{E}-14$ & $9,69 \mathrm{E}-26$ \\
\hline I14 & $1,37 \mathrm{E}-7$ & $9,59 \mathrm{E}-19$ & \\
\hline
\end{tabular}

$\mathrm{n} / \mathrm{s}$ non-significant

Source: authors' elaboration.

the first two indicators only in 2011. On the other hand, in the case of two social (I8, I10) and one geometric indicator (I9) a continuous decrease in significance (in terms of an increasing level of significance) can be observed. For the other indicators alternating tendencies can be seen, either an increase in the significance of space in 2001 compared with 1991 and a decrease in 2011 compared with 2001 (I3, I5, I7, I13), or vice versa, a decline in the significance of space in 2001 as compared with 1991 and an increase in 2011 as compared with 2001 (I6, I11, I12).

We were able to reject $\mathrm{H}_{0}$ and confirm $\mathrm{H}_{1}$, implying that the specific type of rural structure has a statistically significant effect (at the $5 \%$ significance level) on the value of a given indicator, in the case of 10 indicators in 1991 and 2011, and 11 indicators in 2001. This means that at least in the two types of rural structures the values of those indicators are not a coincidence, but a result of a different impact of space in those periods. The initial results of ANOVA confirmed the significance of all the indicators, but for a more detailed insight into the relations of those indicators in the individual types of rural structures we applied Tukey's HSD test (Table 2).

In all types of rural structures there were 6 mutually significant indicators, while in 1991 those were I4, I9, I10 and I14, in 2001 - I7, I9, I11 and I14, and in 2011 - I9 and I11. It is interesting, however, to look at each pair of rural structures, where a gradual decrease in the number of significant indicators between mountain areas and the borderland zone was recorded, as follows: from 9 indicators in 1991 (I4, I7, I8, I9, I10, I11, I12, I13, and I14), to 7 in 2001 (I3, I4, I7, I9, I11, I13, and I14), and only 5 in the last year 2011 (I4, I9, I11, I13, and I14). In turn, the number of significant indicators shared by mountain areas and the intersection zone was more or less settled, with only a minimal increase in their number in the 1991-2001 period, and a minimal decrease in the following period, 2001-2011. In the first period, there were 6 significant indicators (I4, I7, I9, I10, I12, and I14), in 1991 there were 8 (I4, I5, I6, I7, I9, I10, I11, and I14), while in the last year another 6 indicators (I4, I5, I6, I9, I12, and I14) were recorded as significant. In the case of the last pair of rural structures, the borderland zone and the intersection zone, there were 8 significant indicators in the first year (I3, I4, I5, I9, I10, I11, I13, and I14), 10 indicators in 2001 (I3, I5, I6, I9, I10, I11, I12, I13, and I14), and 9 in the last year 2011 (I1, I2, I5, I6, I9, I11, I12, I13, and I14). These findings suggest that over the analysed two decades there was not only a change in the impact of the individual types of rural structure on the monitored indicators, but also between different types of rural structures.

Looking at the results obtained in the statistical investigation, this could signify that all the analysed types of rural structures affect the manifestation of marginality and peripherality similarly (in terms of the number of significant 
Table 2. Tukey's HSD test for post-ANOVA pair-wise comparisons in a one-way ANOVA.

\begin{tabular}{|c|c|c|c|c|c|c|c|c|c|c|}
\hline \multirow{2}{*}{\multicolumn{2}{|c|}{\begin{tabular}{l|ll}
\multicolumn{2}{l}{ Indicator } & Ind
\end{tabular}}} & \multicolumn{3}{|c|}{1991} & \multicolumn{3}{|c|}{2001} & \multicolumn{3}{|c|}{2011} \\
\hline & & & $\mathrm{BO}$ & $\mathrm{I}$ & & $\mathrm{BO}$ & $\mathrm{I}$ & & $\mathrm{BO}$ & $\mathrm{I}$ \\
\hline \multirow{2}{*}{ I1 } & \multirow{2}{*}{ Growth index } & MA & $\mathrm{n} / \mathrm{s}$ & $\mathrm{n} / \mathrm{s}$ & MA & $\mathrm{n} / \mathrm{s}$ & $\mathrm{n} / \mathrm{s}$ & MA & $\mathrm{n} / \mathrm{s}$ & $\mathrm{n} / \mathrm{s}$ \\
\hline & & $\mathrm{BO}$ & & $\mathrm{n} / \mathrm{s}$ & $\mathrm{BO}$ & & $\mathrm{n} / \mathrm{s}$ & $\mathrm{BO}$ & & $\mathrm{P}<.01$ \\
\hline \multirow[t]{3}{*}{$\mathrm{I} 2$} & \multirow{3}{*}{ Population density } & & $\mathrm{BO}$ & $\mathrm{I}$ & & $\mathrm{BO}$ & $\mathrm{I}$ & & $\mathrm{BO}$ & $\mathrm{I}$ \\
\hline & & MA & $\mathrm{n} / \mathrm{s}$ & $\mathrm{n} / \mathrm{s}$ & MA & $\mathrm{n} / \mathrm{s}$ & $\mathrm{n} / \mathrm{s}$ & MA & $\mathrm{n} / \mathrm{s}$ & $\mathrm{n} / \mathrm{s}$ \\
\hline & & $\mathrm{BO}$ & & $\mathrm{n} / \mathrm{s}$ & $\mathrm{BO}$ & & $\mathrm{n} / \mathrm{s}$ & $\mathrm{BO}$ & & $\mathrm{P}<.05$ \\
\hline \multirow[t]{3}{*}{ I3 } & \multirow[t]{3}{*}{ Net migration } & & $\mathrm{BO}$ & $\mathrm{I}$ & & $\mathrm{BO}$ & $\mathrm{I}$ & & $\mathrm{BO}$ & $\mathrm{I}$ \\
\hline & & MA & $\mathrm{n} / \mathrm{s}$ & $\mathrm{n} / \mathrm{s}$ & MA & $\mathrm{P}<.05$ & $\mathrm{n} / \mathrm{s}$ & MA & $\mathrm{n} / \mathrm{s}$ & $\mathrm{n} / \mathrm{s}$ \\
\hline & & $\mathrm{BO}$ & & $\mathrm{P}<.01$ & $\mathrm{BO}$ & & $\mathrm{P}<.01$ & $\mathrm{BO}$ & & $\mathrm{n} / \mathrm{s}$ \\
\hline \multirow[t]{3}{*}{$\mathrm{I} 4$} & \multirow[t]{3}{*}{ Index of education } & & $\mathrm{BO}$ & $\mathrm{I}$ & & $\mathrm{BO}$ & $\mathrm{I}$ & & $\mathrm{BO}$ & $\mathrm{I}$ \\
\hline & & MA & $\mathrm{P}<.01$ & $\mathrm{P}<.01$ & MA & $\mathrm{P}<.01$ & $\mathrm{P}<.01$ & MA & $\mathrm{P}<.01$ & $\mathrm{P}<.01$ \\
\hline & & $\mathrm{BO}$ & & $\mathrm{P}<.05$ & $\mathrm{BO}$ & & $\mathrm{n} / \mathrm{s}$ & $\mathrm{BO}$ & & $\mathrm{n} / \mathrm{s}$ \\
\hline \multirow[t]{3}{*}{ I5 } & \multirow[t]{3}{*}{ Index of economic dependence } & & $\mathrm{BO}$ & $\mathrm{I}$ & & $\mathrm{BO}$ & $\mathrm{I}$ & & $\mathrm{BO}$ & $\mathrm{I}$ \\
\hline & & MA & $\mathrm{n} / \mathrm{s}$ & $\mathrm{n} / \mathrm{s}$ & MA & $\mathrm{n} / \mathrm{s}$ & $\mathrm{P}<.01$ & MA & $\mathrm{n} / \mathrm{s}$ & $\mathrm{P}<.01$ \\
\hline & & $\mathrm{BO}$ & & $\mathrm{P}<.01$ & $\mathrm{BO}$ & & $\mathrm{P}<.01$ & $\mathrm{BO}$ & & $\mathrm{P}<.01$ \\
\hline \multirow[t]{3}{*}{ I6 } & \multirow[t]{3}{*}{ Ageing index } & & $\mathrm{BO}$ & $\mathrm{I}$ & & $\mathrm{BO}$ & I & & $\mathrm{BO}$ & I \\
\hline & & MA & $\mathrm{n} / \mathrm{s}$ & $\mathrm{n} / \mathrm{s}$ & MA & $\mathrm{n} / \mathrm{s}$ & $\mathrm{P}<.01$ & MA & $\mathrm{n} / \mathrm{s}$ & $\mathrm{P}<.01$ \\
\hline & & $\mathrm{BO}$ & & $\mathrm{n} / \mathrm{s}$ & $\mathrm{BO}$ & & $\mathrm{P}<.01$ & $\mathrm{BO}$ & & $\mathrm{P}<.01$ \\
\hline \multirow[t]{3}{*}{ I7 } & \multirow[t]{3}{*}{ Unemployment rate } & & $\mathrm{BO}$ & $\mathrm{I}$ & & $\mathrm{BO}$ & $\mathrm{I}$ & & $\mathrm{BO}$ & I \\
\hline & & MA & $\mathrm{P}<.01$ & $\mathrm{P}<.05$ & MA & $\mathrm{P}<.01$ & $\mathrm{P}<.01$ & MA & $\mathrm{n} / \mathrm{s}$ & $\mathrm{n} / \mathrm{s}$ \\
\hline & & $\mathrm{BO}$ & & $\mathrm{n} / \mathrm{s}$ & $\mathrm{BO}$ & & $\mathrm{P}<.01$ & $\mathrm{BO}$ & & $\mathrm{n} / \mathrm{s}$ \\
\hline \multirow[t]{3}{*}{ I8 } & \multirow[t]{3}{*}{ Ethnic diversity } & & $\mathrm{BO}$ & I & & $\mathrm{BO}$ & I & & $\mathrm{BO}$ & $\mathrm{I}$ \\
\hline & & MA & $\mathrm{P}<.05$ & $\mathrm{n} / \mathrm{s}$ & MA & $\mathrm{n} / \mathrm{s}$ & $\mathrm{n} / \mathrm{s}$ & MA & $\mathrm{n} / \mathrm{s}$ & $\mathrm{n} / \mathrm{s}$ \\
\hline & & $\mathrm{BO}$ & & $\mathrm{n} / \mathrm{s}$ & $\mathrm{BO}$ & & $\mathrm{n} / \mathrm{s}$ & $\mathrm{BO}$ & & $\mathrm{n} / \mathrm{s}$ \\
\hline \multirow[t]{3}{*}{ I9 } & \multirow{3}{*}{$\begin{array}{l}\text { Distance from the centre with min. } 20 \text { thou- } \\
\text { sand inhabitants }\end{array}$} & & $\mathrm{BO}$ & I & & $\mathrm{BO}$ & $\mathrm{I}$ & & $\mathrm{BO}$ & I \\
\hline & & MA & $\mathrm{P}<.01$ & $\mathrm{P}<.01$ & MA & $\mathrm{P}<.01$ & $\mathrm{P}<.01$ & MA & $\mathrm{P}<.01$ & $\mathrm{P}<.01$ \\
\hline & & $\mathrm{BO}$ & & $\mathrm{P}<.01$ & $\mathrm{BO}$ & & $\mathrm{P}<.01$ & $\mathrm{BO}$ & & $\mathrm{P}<.01$ \\
\hline $\mathrm{I} 10$ & Share of indigenous inhabitants & & $\mathrm{BO}$ & $\mathrm{I}$ & & $\mathrm{BO}$ & I & & $\mathrm{BO}$ & I \\
\hline & & MA & $\mathrm{P}<.01$ & $\mathrm{P}<.01$ & MA & $\mathrm{n} / \mathrm{s}$ & $\mathrm{P}<.01$ & MA & $\mathrm{n} / \mathrm{s}$ & $\mathrm{n} / \mathrm{s}$ \\
\hline & & $\mathrm{BO}$ & & $\mathrm{P}<.01$ & $\mathrm{BO}$ & & $\mathrm{P}<.01$ & $\mathrm{BO}$ & & $\mathrm{n} / \mathrm{s}$ \\
\hline I11 & Share of economically active people leaving for & & $\mathrm{BO}$ & I & & $\mathrm{BO}$ & I & & $\mathrm{BO}$ & I \\
\hline & work & MA & $\mathrm{P}<.01$ & $\mathrm{n} / \mathrm{s}$ & MA & $\mathrm{P}<.01$ & $\mathrm{P}<.05$ & MA & $\mathrm{P}<.01$ & $\mathrm{n} / \mathrm{s}$ \\
\hline & & $\mathrm{BO}$ & & $\mathrm{P}<.01$ & $\mathrm{BO}$ & & $\mathrm{P}<.01$ & $\mathrm{BO}$ & & $\mathrm{P}<.01$ \\
\hline I12 & Progressivity of economic structure & & $\mathrm{BO}$ & $\mathrm{I}$ & & $\mathrm{BO}$ & $\mathrm{I}$ & & $\mathrm{BO}$ & $\mathrm{I}$ \\
\hline & & MA & $\mathrm{P}<.01$ & $\mathrm{P}<.01$ & MA & $\mathrm{n} / \mathrm{s}$ & $\mathrm{n} / \mathrm{s}$ & MA & $\mathrm{n} / \mathrm{s}$ & $\mathrm{P}<.01$ \\
\hline & & $\mathrm{BO}$ & & $\mathrm{n} / \mathrm{s}$ & $\mathrm{BO}$ & & $\mathrm{P}<.01$ & $\mathrm{BO}$ & & $\mathrm{P}<.01$ \\
\hline I13 & Share of unoccupied dwellings & & $\mathrm{BO}$ & I & & $\mathrm{BO}$ & I & & $\mathrm{BO}$ & I \\
\hline & & MA & $\mathrm{P}<.01$ & $\mathrm{n} / \mathrm{s}$ & MA & $\mathrm{P}<.01$ & $\mathrm{n} / \mathrm{s}$ & MA & $\mathrm{P}<.01$ & $\mathrm{n} / \mathrm{s}$ \\
\hline & & $\mathrm{BO}$ & & $\mathrm{P}<.01$ & $\mathrm{BO}$ & & $\mathrm{P}<.01$ & $\mathrm{BO}$ & & $\mathrm{P}<.01$ \\
\hline I14 & Index of infrastructural facilities & & $\mathrm{BO}$ & I & & $\mathrm{BO}$ & I & & $\mathrm{BO}$ & I \\
\hline & & MA & $\mathrm{P}<.05$ & $\mathrm{P}<.01$ & MA & $\mathrm{P}<.01$ & $\mathrm{P}<.01$ & MA & $\mathrm{P}<.01$ & $\mathrm{P}<.05$ \\
\hline & & $\mathrm{BO}$ & & $\mathrm{P}<.01$ & $\mathrm{BO}$ & & $\mathrm{P}<.01$ & $\mathrm{BO}$ & & $\mathrm{P}<.01$ \\
\hline
\end{tabular}

$\mathrm{BO}$ - borderland

MA - mountain areas

I - intersection of mountain areas and borderland

Source: authors' elaboration.

indicators and their equal position in the analysis). However, from the perspective of the nature of individual indicators, this is not quite correct as an ultimate conclusion. In other words, from the changing significance of individual indicators one can deduce that in different kinds of the rural environment (the type of rural structure) various indicators appear to play a key role. For instance, in the case of mountain areas and the borderland zone, socio-spatial polarisation was most significantly influenced by indicators related to education, distance from a regional centre, 
economically active population, and infrastructural facilities (I1, I9, I11, and I14). In the case of mountain areas and the intersection zone it was mostly education, distance from a regional centre and infrastructure that mattered most (I4, I9, and I14), and as to the borderland and the intersection zone, the most significant indicators were economic dependence, distance from a regional centre, economically active population, unoccupied dwellings, and infrastructure (I5, I9, I11, I13, and I14).

Another interesting finding emerging from the analysis is the fact that three indicators (I1, I2 and I8) were significant only between two types of rural structures in one year. Moreover, in the case of I2 and I8, the values were only slightly below the level of significance $(\alpha<0.5)$. Although these results could suggest excluding those indicators from analysis, we believe that they still represent a relevant aspect of the phenomenon of socio-spatial polarisation despite the fact that the influence of space as such can be rather neglected here. We could identify two reasons for that. In the case of population density (I2), it is generally low in rural areas, particularly if they are located on the periphery (near the state borders, administrative borders, or at hard-to-reach altitudes). When looking at the ethnic diversity index (I8), this is mainly influenced by data available for calculation provided by the Statistical Office of the Slovak Republic (ŠUSR), which tend to underestimate the reality. Generally, it is believed that this source of data provides only a partial, often underestimated view of the Roma population, mainly in comparison with the results of other partial surveys published in the Atlas of Roma communities in Slovakia in 2004 and 2013. Therefore, it would be interesting to see whether and how the level of significance would vary when using those data.

The rejection of the null hypothesis $\left(\mathrm{H}_{0}\right)$ set out in the framework of our ANOVA, together with the results of Tukey's HSD test, revealed not only that each type of rural structure had a different impact on the values of the indicators representing partial dimensions of marginality and peripherality, but ultimately contributed to the verification of one of the key assumptions set out in this study: that the phenomenon of marginality and peripherality (in other words, socio-spatial polarisation) is manifested differently in the specific types of the rural environment, and that its character changes over time. Last but not least, the results point out to the merit of the research on the rural environment with respect to individual types of rural structures (in our case determined by the parameter of a higher altitude and a specific location in the borderland), but in particular they show how the specificity of space and place can influence the formation and manifestation of socio-spatial polarisation in different ways.

\section{Concluding remarks}

It is generally believed that rural areas have a greater tendency to lag behind socio-economic development in comparison with the urban environment (Scott 1998). Not to mention the spatial significance of rurality, since nearly $80 \%$ of the EU are rural areas, as well as its importance in terms of settlement, since nearly $25 \%$ of the EU population resides here. In the case of the Slovak rural environment, these figures are $86 \%$ and $40 \%$, respectively, which makes rural areas prevalent in the settlement structure of Slovakia. Moreover, rural municipalities represent more than $95 \%$ of their total number, with a vast majority (over 90\%) with the population below 2,000 (Gajdos, Pašiak 2008), usually regarded as the most vulnerable in terms of effective functioning and development; even more when considering rural regions and rural societies in post-socialist Central Europe, where the transformation process has resulted in extremely polarised regional development (Leibert 2013).

The issue of rural areas has therefore a relatively large spatial context. Due to its diversity and multidimensionality, it can be studied from many perspectives, opening up new avenues of research. In our study we looked at the rural environment through the lens of what is traditionally understood as a geographical perspective. In our case this required an effort to seek and understand where socio-spatial polarisation could be found, why this phenomenon occurred in specific places, and how specific conditions in the same or distant places influenced those places and effected socio-spatial polarisation over time. The results of a one-way ANOVA analysis draw our attention to some interesting findings. 
First of all, the results of this analysis and the subsequent Tukey's HSD tests confirmed that different rural spaces (in our case mountain areas, the borderland zone and their intersection) affected the presence and manifestation of the phenomenon of marginality and peripherality differently over time, which points out to the merit of rural research in relation to specificities of individual rural structures. The character of each region, especially if we talk about rural areas, is in fact influenced by the long-term mutual interaction between the environment and society. Therefore, when studying the rural environment, it is inevitable to consider its historical development where, in addition to man as a factor affecting the countryside, space and especially natural physical and geographical conditions also play a role (Lauko 2003).

The analysis of the selected set of indicators implying socio-spatial polarisation over two decades shows that the character of this phenomenon keeps changing over time, not only between individual rural structures, but within every type of rural structure as such. In this respect, we were able to verify our working hypothesis that the phenomenon of marginality and peripherality (socio-spatial polarisation) is expressed differently in the specific types of rural structures, and that the character of its manifestation changes over time. With the use of ANOVA we confirmed that those differences were not just a coincidence, but rather an outcome of the influence of space and place and their specific characteristics. Generally, the most influential indicators in all the analysed time-space conditions appear to be those related to the distance from regional centres - a centre with less than 20,000 inhabitans (I9), and infrastructural facilities (I14). Looking at the first indicator (I9), this shifts our attention to the origin of regional disparities and to the cornerstone of the core-periphery model (as developed by Leimgruber 1994, 2004 and Schmidt 1998), and the concept of so-called uneven geography of the countryside, shaped by globalisation procesess (McDonagh et al. 2015), and where the physical geographical aspect still matters. Moreover, since mountain areas and especially the borderland zone are typically in a peripheral location often characterised by a reduced sphere of influence (in terms of Newton's law), the distance or the kind of isolation plays a key determining role here. As to the second indicator (I14), the absence of basic infrastructure is still one of the most fundamental problems for many areas with difficult access (including mountain areas and some borderland zones), and an improvement in this unfavourable situation, unfortunately, does not seem to be close.

It is, however, relevant to stress that not all mountain areas or all borderland zones must display the features of marginality or peripherality. In fact, many authors have already highlighted it in their theoretical considerations, attributing these differences mainly to the lack of integration of certain areas and their exclusion from main economic, social and cultural processes (Schmidt 1998), as a result of their different ability to adapt to the changing economic, social and political structures, which often go beyond physical disadvantages (Mehretu et al. 2000; Halás 2002; Leimgruber 2004; Pelc 2011). Last but not least, although in our study we uncovered another small piece in a huge package of issues in rural research, it is still necessary to conduct our investigation further in order to better understand the complex nature of rural areas worldwide.

\section{Acknowledgements}

This contribution was supported by VEGA Grant No. 1/0745/16 "Autonomy, interdependence and interactions of spatial systems".

\section{References}

Anderson J., O’Dowd L., 1999. Borders, border regions and territoriality: Contradictory meanings, changing significance. Regional Studies 33(7): 593-604.

Andreoli M., 1994. Development and marginalisation in Liguria region. In: Chang Y.D. (ed.), Marginality and development issues in marginal regions. Proceedings of the IGU Study Group. Taipei: 41-60.

Appadurai A., 1997. Modernity at large. Cultural dimensions of globalisation. University of Minesota Press, Minneapolis.

Atlas rómskych komunít na Slovensku 2004. [online]. [cit. 201601-15]. Available at: http://www.romovia.vlada.gov. sk/20535/atlas-romskych-komunit.php.

Atlas rómskych komunít na Slovensku 2013. [online]. Regionálne centrum rozvojového programu OSN pre Európu a Spoločenstvo nezávislých štátov, Bratislava. [cit. 2016-01-15]. Available at: http://www.minv.sk/?atlas_2013.

Bezák P., Mitchley J., 2014. Drivers of change in mountain farming in Slovakia: from socialist collectivisation to the Common Agricultural Policy. Regional Environmental Change 14(4): 1343-1356. 
Binek J., Svobodová H., 2009. Rozvoj venkova a rozvoj regionů: Společná zemědělská politika a regionální politika na jednom hřišti. Regionální studia 3(1): 12-19.

Binek J., Svobodová H., Holeček J., Galvasová I., Chabičovská K., 2010. Synergie ve venskovském prostoru - Př́stupy $k$ řešení problémů rozvoje venkovských obcí. GaREP Publishing, Brno.

Binek J., Svobodová H., Holeček J., Galvasová I., Chabičovská K., 2011. Synergie ve venkovském prostoru - Paradoxy rozvoje venkova. GaREP Publishing, Brno.

Binek J., Toušek V., Galvasová I., Věžník A., Kunc J., Seidenglanz D., Halásek D., Rehák S., 2007. Venkovský prostor a jeho oživení. Georgetown, Brno.

Buchta S., 2003. Slovenský vidiek na konci dvadsiateho storočia. Sociológia-Slovak Sociological Review 2: 125-140.

Cloke P., 1980. New emphases for applied rural geography. Progress in Human Geography 4: 181-217.

Cloke P., 2006. Conceptualising rurality. In: Cloke P., Marsden T., Mooney P. (eds), Handbook of Rural Studies. Sage, London: 18-28.

Cloke P., Milbourne P., 1992. Deprivation and lifestyles in rural Wales - II. Rurality and the cultural dimension. Journal of Rural Studies 8(4): 359-371.

Clout H., 1982. Rural settlements. Progress in Human Geography 6(3): 425-430.

Creamer C., Blair N., Keaveney K., O’Keeffe B., Driscoll J., 2009. Rural restructuring: local sustainable solutions to the rural challenge. International Centre for Local and Regional Development (ICLRD)

Danglová O., 2005. Vidiek v procese transformácie. Výsledky etnografického výskumu jedného západoslovenského regiónu. Zing Print, Bratislava.

Danglová O., 2006. Slovenský vidiek. Bariéry a perspektívy rozvoja. Ústav etnológie SAV, Bratislava.

Džupinová E., Halás M., Horňák M., Hurbánek P., Káčerová M., Michniak D., Ondoš S., Rochovská A., 2008. Periférnost' a priestorová polarizácia na území Slovenska. Bratislava, Geo-grafika.

Falt'an L'., Gajdoš P., Pašiak J., 1995. Sociálna marginalita území Slovenska. Social marginality of territories of Slovakia. SPACE Centrum pre analýzu sociálnej politiky, Bratislava.

Fáziková M., 2006. Procesy reštrukturalizácie v ekonomickej základni vidieckych regiónov v Slovenskej republike. Acta Regionalia et Environmentalica 3: 1-7.

Ferrao J., Lopez R., Ferreiro F., 2003. Rurality, peripherality and rural areas in Europe. In: Labrianidis L. (ed.), The future of Europe's rural periphery, the role of entrepreneurship in responding to employment problems and social marginalisation. EU Research on Social Sciences and Humanities, European Commision's final report: 66-94.

Gajdoš P., 2000. Transformačné zmeny regionálnych štruktúr vidieckej krajiny Horehronia v 20. storočí. Geografické štúdie 7: 77-82.

Gajdoš P., Pašiak J., 2008. Sociálne zdroje lokálneho a regionálneho rozvoja. Sociologický ústav SAV, Bratislava.

Giddens A., 1984. The constitution of society. Outline of the theory of structuration. University of California Press, Berkeley and Los Angeles.

Goodwin M., Cloke P., Milbourne P., 1995. Regulation theory and rural research: Theorising contemporary rural change. Environment and Planning A 27(8): 1245-1260.

Gregory D., Johnston R., Pratt G., Watts M., Whatmore S., 2009. The dictionary of human geography. $5^{\text {th }}$ edition. Wiley-Blackwell.
Halás M., 2005. Vidiek v prihraničných regiónoch. In: Spišiak P., Kusendová D., Pavlíčková K., Halás M., Kolény M., Zubriczký G., Švoňavec M., Hurbánek P., Pal'uch T., Labuda M. (eds), Agrorurálne štruktúry Slovenska po roku 1989. Geografika, Bratislava: 114-122.

Halás M., 2008. Priestorová polarizáca spoločnosti s detailným pohl'adom na periférne regióny Slovenska. Sociologický časopis/ Czech Sociological Review 44(2): 349-369.

Halfacree K.H., 1993. Locality and social representation: Space, discourse and alternative definitions of the rural. Journal of Rural Studies 9(1): 23-37.

Halfacree K.H., 2006. Rural space: Constructing a three-fold architecture. In: Cloke P., Marsden T., Mooney P. (eds), Handbook of rural studies. Sage, London: 44-62.

Halseth G., Markley S., Bruce D., 2010. The next rural economies. Constructing rural place in global economies. CABI Publishing.

Havlíček T. 2003. Are border regions peripheral regions? In: Kowalczyk A. (ed.), Theoretical and methodological aspects of geographical space at the turn of the century. Warsaw University, Warsaw: 193-197.

Havlíček T., Chromý P., Jančák V., Marada M., 2005. Vybrané teoreticko-metodologické aspekty a trendy geografického výzkumu periferních oblastí. In: Novotná M. (ed.), Problémy periferních oblastí. Univerzita Karlova v Praze, Př́rodovědecká fakulta, Katedra sociální geografie a regionálního rozvoje: 6-24.

Heřmanová E., 1991. Vybrané vícerozměrné statistické metody $v$ geografii. Státní pedagogické nakladatelství, Univerzita Karlova v Praze.

Hoggart K., 1988. Not a definiton of rural. Area 20(1): 35-40.

Hoggart K., 1990. Let's do away with rural. Journal of Rural Studies 6(3): 245-257.

Hoggart K., Paniagua A., 2001a. What rural restructuring? Journal of Rural Studies 17(1): 41-62.

Hoggart K., Paniagua A., 2001b. The restructuring of rural Spain? Journal of Rural Studies 17(1): 63-80.

Hrabánková M., Rolínek L., Řehoř P., Čermáková A., Navrátil J., 2009. Identifikace sociálnĕ-ekonomických podminek rozvoje horských a podhorských oblastí. Jihočeská univerzita v Českých Budějovicích.

Hruška V., 2014. Proměny přístupů ke konceputalizaci venkovského prostoru v rurálních studiích. Sociologický časopis/ Czech Sociological Review 4: 581-601.

Chajdiak J., 2015. Tri poznámky k demografickému vývoju v Slovenskej republike. In: Transformácia slovenskej spoločnosti vo svetle výsledkov posledných troch populačných cenzov. Zborník príspevkov z 15. Slovenskej demografickej konferencie, Trenčianske Teplice, 17-18. septembra 2015, 34-35.

Chajdiak J., Rublíková E., Gudába M., 1997. Štatistické metódy v praxi. STATIS, Bratislava.

Chambers R., 1983. Rural development: Putting the last first. Routledge.

Ilbery B., 1998. The geography of rural change. Peason Education Limited.

Informačný servis Vúpop. Pôdny portál Výskumného ústavu pôdoznalectva a ochrany pôdy. [online]. [cit. 2015-0115]. Available at: http:// www.podnemapy.sk/ portal/ prave_menu/lfa/lfa.aspx.

Ira V., 2003. Rural space in Slovakia: Changes of spatial structures and spatial behavioural patterns. Acta Universitatis Carolinae-Geographica 38(1): 119-130. 
Ira V., Huba M., 1999. Changes of rural space in Slovakia from sustainability perspective. Geographica Slovenica 31: 151-161.

Jeřábek M., Dokoupil J., Havlíček T., 2004. České pohraničíbariéra nebo prostor zprostředkování? Academia, Prague.

Juhaščíková I., Škápik P., Štukovská Z., 2015. Vplyv transformácie spoločnosti na ekonomickú aktivitu podla výsledkov troch samostatných cenzov. In: Transformácia slovenskej spoločnosti vo svetle výsledkov posledných troch populačných cenzov. Zborník príspevkov z 15. Slovenskej demografickej konferencie, Trenčianske Teplice, 17-18. septembra 2015, 55-62.

Jussila H., Leimgruber W., Majoral R., 1998. Perception of marginality: Theoretical issues and regional perceptions of marginality. Ashgate, Aldershot.

Klinda J., 2007. Slovenská Krajina. Enviromagazín 1: 3.

Kubeš J., 2000. Problémy stabilizace venkovského osídlení ČR. Jihočeská univerzita v Českých Budějovicích, České Budejovice.

Labrianidis L. (ed.). 2004. The future of Europe's rural peripheries. Ashgate, Aldershot.

Lauko V., 2003. Transformation of service network in Bratislava's hinterland region. Acta Universitatis Carolinae. Geographica 38(1): 219-230.

Leibert T., 2013. The peripheralisation of rural areas in post-socialist Central Europe: A case of fragmenting development? Lessons from rural Hungary. In: Naumann M., Fischer-Tahir A. (eds), Peripheralisation: The making of spatial dependencies and social injustice. Springer Science and Business Media: 101-120.

Leimgruber W., 1994. Marginality and marginal regions: Problems of definition. In: Chang Y.D. (ed.), Marginality and development issues in marginal regions. Proceedings of the IGU Study Group. Taipei: 1-18.

Leimgruber W., 2004. Between global and local: Marginality and marginal regions in the context of globalisation and deregulation. Ashgate, Aldershot.

Leimgruber W., Zsilincsar W., Nel E., 2011. Mountain regions in transformation. Global processes, regional and local impacts and responses. Proceedings of the 2010 Conference in Graz and Fribourg.

Lier H.N., 1996. Sustainable rural systems: Concepts from land use planners perspective. In: Sasaki H., Saito I., Tabayashi A., Morimoto T. (eds), Geographical perspectives on sustainable rural systems. Proceedings of the Tsukuba International Conference on the Sustainability of Rural Systems. Kaisei, Japan: 14-25.

Máliková L., 2014. Zmena využitia zeme vo vybraných pol'nohospodársky znevýhodnených oblastiach SR. In: Zborník príspevkov študentskej vedeckej konferencie 2014 (Bratislava, 9.4 2014). Prírodovedecká fakulta, Univerzita Komenského: 1437-1442.

Máliková L., Farrell M., McDonagh J., 2016. Perception of marginality and peripherality within an Irish rural context. Quaestiones Geographicae 35(4): 93-105.

Máliková L., Klobučník M., Bačík V., Spišiak P., 2015. Socio-economic changes in the borderlands of the Visegrad Group (V4) countries. Moravian Geographical Reports 23(2): 26-37.

Marek T., 2004. Sociální sitě, aktéři a instituce v regionálním rozvoji. Sborník prací z mezinárodní vědecké konference Agrární perspektivy XIII. PEF ČZU, Praha: 831-835.

Markechová D., Stehlíková B., Tirpáková A., 2011. Štatistické metódy a ich aplikácie. Univerzita Konštantína Filozofa v Nitre, Nitra.
Marsden T., 1998. New rural territories: Regulating the diversified rural spaces. Journal of Rural Studies 14(1): 107-117.

Marsden T., Lowe P., Whatmore S., 1990. Rural restructuring: Global processes and their responses. David Fulton Publishers Ltd.

Marsden T., Murdoch J., Lowe P., Munton R. C., Flynn A., 1993. Constructuring the countryside: An approach to rural development. Routledge, London.

McDonagh J. 2001. Renegotiating rural development in Ireland. Ashgate, Aldershot.

McDonagh J. (ed.), 2002. Economy, society, and peripherality: Experiences from the west of Ireland. Arlen House, Galway.

McDonagh J., Nienaber B., Woods M., 2015. Globalisation and Europe's rural regions. Ashgate, Aldershot.

Mehretu A., Pigozzi B.W., Sommers L.M., 2000. Concepts in social and spatial marginality. Geografiska Annaler 82 B (2): 89-101.

Meredith D., 2010. Rural areas in transition: Evidence of rural restructuring in the Republic of Ireland. In: Winchell D.D., Ramsey D., Koster R., Robinson G.M., Geographical perspectives on sustainable rural change. Rural Development Institute: 220-242.

Michálek A., 2015. Identifikácia a zmeny marginálnych regiónov na Slovensku (z aspektu sociálno-ekonomickej marginality). Ekonomický časopis 63(9): 922-943.

Mikuš R., Máliková L., Lauko V., 2016. An introductory study of perceptual marginality in Slovakia. Bulletin of Geography 34: 47-62.

Miller J., Haden P., 2006. Statistical analysis with the general linear model. Creative Commons Attribution.

Moseley M.J., 2003. Rural development: Principles and practice. SAGE, London.

Murdoch J., Marsden T., 1994. Reconstituting rurality. Class, community and power in the development process. University College, London.

Murdoch J., Pratt A., 1993. Rural studies: Modernism, postmodernism and the 'post-rural'. Journal of Rural Studies 9(4): 321-348.

Nelles J., Durand F., 2012. Political rescaling and metropolitan governance in cross-border regions: Comparing the cross-border metropolitan areas of Lille and Luxembourg. European Urban and Regional Studies 21(1): 104-122.

Newman D., 2006. The lines that continue to separate us: Borders in a 'borderless' world. Progress in Human Geography 30(1): 143-161.

Novotná M., 2011. Problémy venkovských oblastí. Habilitačná práca. Provozně ekonomická fakulta, Česká zemědělská univerzita v Praze.

Novotný L., Hruška V., Egedy T., Mazur M., 2015. Defining rural areas of Visegrad countries. Studia Obszarów Wiejskich 39: 21-34.

Novotný L., Mazur M., Egedy T., 2015. Definition and delimitation of peripheries of Visegrad countries. Studia Obszarów Wiejskich 39: 35-48.

O'Dowd L., 2001. State borders, border regions band the construction of European identity. In: Kohli M., Novak M. (eds), Will Europe work? Integration, employment and the social order. Routledge: 95-110.

Paasi A., 2012. Border studies reanimated: Going beyond the territorial/ relational divide. Environment and Planning A 44(10): 2303-2309.

Pacione M., 1984. Rural geography. Harper and Row, London.

Pelc S., 2011. Demographic trends and threats. In: Leimgruber W., Zsilincsar W., Nel E. (eds), Mountain regions in transformation. Global processes, regional and local impacts 
and responses. Proceedings of the 2010 Conference in Graz and Fribourg: 47-66.

Pileček J., 2005. Příspěvek k metodice vymezování periferních oblastí: modelové území okresu Prachatice. In: Novotná M. (ed.), Problémy periferních oblastí. Univerzita Karlova v Praze, Př́rodovědecká fakulta, Katedra sociální geografie a regionálního rozvoje: 81-91.

Podolák P., 1999. Demographic aspects of changes in rural areas. Geographica Slovenica 31: 162-169.

Rogerson P., 2001. Statistical methods for geography. Sage Publications, London.

Sasaki H., Saito I., Tabayashi A., Morimoto T., 1996. Geographical perspectives on sustainable rural systems. Proceedings of the Tsukuba International Conference on the Sustainability of Rural Systems. Kaisei, Japan.

Shucksmith M., 1990. The definition of rural areas and rural deprivation. Scottish Homes, Edinburgh.

Schmidt M.H., 1998. An integrated systemic approach to marginal regions: from definition to development policies. In: Jussila H., Leimgruber W., Majoral R. (eds), Perception of marginality: Theoretical issues and regional perceptions of marginality. Ashgate, Aldershot: 45-66.

Schmidt M.H., 2007. Some reflections on the definition and delimitation of geographical marginality. In: Jones G., Leimgruber W., Nel E. (eds), Issues in geographical marginality. General and theoretical aspects. International Geographical Union: 34-43.

Schmidt M.H., 2011. Local transformations in mountain areas influenced by globalisation. A case in Mendoza, Argentina. In: Leimgruber W., Zsilincsar W., Nel E. (eds), Mountain regions in transformation. Global processes, regional and local impacts and responses. Proceedings of the 2010 Conference in Graz and Fribourg: 153-168.

Scott P., 1998. Development issues in marginal regions. In: Jussila H., Leimgruber W., Majoral R. (eds), Perception of marginality: Theoretical issues and regional perceptions of marginality. Ashgate, Aldershot: 1998: 7-26.

Sommers L.M., Mehretu A., 1998. International perspectives on socio-spatial marginality. In: Jussila H., Leimgruber W., Majoral R. (eds), Perception of marginality: Theoretical issues and regional perceptions of marginality. Ashgate, Aldershot: 135-145.
Spišiak P., 1998. Trvalá udržatel'nost' rurálnych systémov. In: Implementácia trualo udržatelného rozvoja. ÚKE SAV, Bratislava: 286.

Spišiak P., 2000. Pol'nohospodárstvo v marginálnych oblastiach Slovenska. Životné prostredie 34(1): 15-19.

Spišiak P., 2003. Sustainability of rural areas in Slovakia. In: Kowalczyk A. (ed.), Theoretical and methodological aspects of geographical space at the turn of the century. Warsaw University: 277-284.

Spišiak P., 2005. Rozvoj vidieka v mikroregionálnych štruktúrach Slovenska. Acta Facultatis Rerum Naturalium, Geographica, Supplementum Nr. 3: 567-573.

Spišiak P., Kusendová D., Pavlíčková K., Halás M., Kolény M., Zubriczký G., Švoňavec M., Hurbánek P., Pal'uch T., Labuda M. (eds), 2005. Agrorurálne štruktúry Slovenska po roku 1989. Geografika, Bratislava.

Tykkyläinen M., 1998. From territorial marginality to marginality in cybersociety. In: Jussila H., Leimgruber W., Majoral R. (eds), Perception of marginality: Theoretical issues and regional perceptions of marginality. Ashgate, Aldershot: $123-134$.

Výskumný ústav pôdoznalectva a ochrany pôdy (VUPOP). Pol'nohospodársky znevýhodnené oblasti SE - LFA. [online]. [cit. 2016-01-15]. Available at: http:// www.podnemapy.sk/ portal/prave_menu/lfa/lfa.aspx.

Winchell D.D., Ramsey D., Koster R., Robinson G.M., 2010. Geographical perspectives on sustainable rural change. Rural Development Institute.

Woods M., 2005. Rural geography: Processes, responses and experiences in rural restructuring. Sage Publications, London.

Woods M., 2009. Rural geography: Blurring boundaries and making connections. Progress in Human Geography 33(6): 849-858.

Woods M., 2010. The political economies of place in the emergent global countryside: Stories from rural Wales. In: Halseth G., Markley S., Bruce D. (eds), The next rural economies. Constructing rural place in global economies. CABI Publishing: 166-178.

Woods M., 2011. Rural. Routledge, London.

Zubriczký G., 2000. Restructuring the rural landscapes in Slovakia. EGEA Magazine 2: 5-10.

Zubriczký G., 2002. Analýza rurálneho priestoru Slovenska z hl'adiska rozvojových perspektív jeho osídlenia. Regionálnogeografické štúdie 1: 67-120. 